\title{
Effect of general dietary deficiency and protein malnutrition on the fibrogenesis caused by silica dust in rats
}

\author{
S. H. ZAIDI and J. L. KAW \\ Industrial Toxicology Research Centre, Chattar Manzil Palace, Lucknow, India
}

\begin{abstract}
Zaidi, S. H., and Kaw, J. L. (1970). Brit. J. industr. Med., 27, 250-259. Effect of general dietary deficiency and protein malnutrition on the fibrogenesis caused by silica dust in rats. In order to determine whether the dietary deficiency, which may occur in miners in India, is likely to influence their response to silica dust, two experiments were carried out on rats. In both experiments rats were exposed to silica dust by intratracheal inoculation of saline suspension, the dose being sufficient to cause marked fibrosis in normal rats. In the first experiment rats were fed on a multiple deficient diet and in the second on a diet grossly deficient in protein but otherwise adequate. Although these diets caused other evidence of dietary deficiency, in neither group was there any difference in the extent of silicotic fibrosis as assessed by histological or biochemical methods.
\end{abstract}

In some developing countries, that section of the population from which miners are recruited is known to be living on a multiple deficient diet. This situation exists in India and the general implications of the diet have been discussed by several workers (Aykroyd and Krishnan, 1937; Mason, Theophilus, and Frimodt-Möller, 1945; Sriramachari, Ramalingaswami, and Patwardhan, 1958). Miners on this deficient diet show growth retardation and often oedema, depigmentation of the hair, dermatoses, microcytic or normochromic anaemia, and a reduction in blood cholesterol and plasma proteins. Fatty infiltration and, in advanced cases, cirrhosis of the liver also occur. This paper describes experiments on rats designed to determine whether this diet is likely to alter the reaction of the lung to silica dust. In one experiment the rats exposed to silica dust were fed on a diet deficient in proteins, minerals, and vitamins similar to that on which the miners live. Because other workers (Bhuyan, Nayak, Deo, and Ramalingaswami, 1965; Stary, McMillan, and Weigensberg, 1966) have suggested that protein is essential for rapid fibrogenesis, the experiment was repeated on a group of animals on a diet adequate in everything except protein. Because preliminary studies (Chvapil, 1957) over a short term were inconclusive the experiments were continued for at least 180 days.

\section{Materials and methods}

\section{Preparation of dust sample}

Quartz dust below 52 microns particle size was obtained from the Central Glass and Ceramic Research Institute, Calcutta. This sample was chemically pure and contained only faint traces of impurities. A sample containing particles less than $4 \mu$ by number and mass was prepared by repeated sedimentation in distilled water (Zaidi, 1969). Details of the size distribution and chemical composition of the quartz samples used in the present experiment are given in Table 1.

\section{Preparation of dust suspension}

A weighed quantity of dust was added to physiological saline solution to give a final concentration of $50 \mathrm{mg} / \mathrm{ml}$. The solution was autoclaved in screw-capped bottles at $15 \mathrm{lb}$ for 30 minutes and kept agitated until used. 
TABLE 1

Size Distribution and Chemical ANALYSIS OF QUARTZ DUST

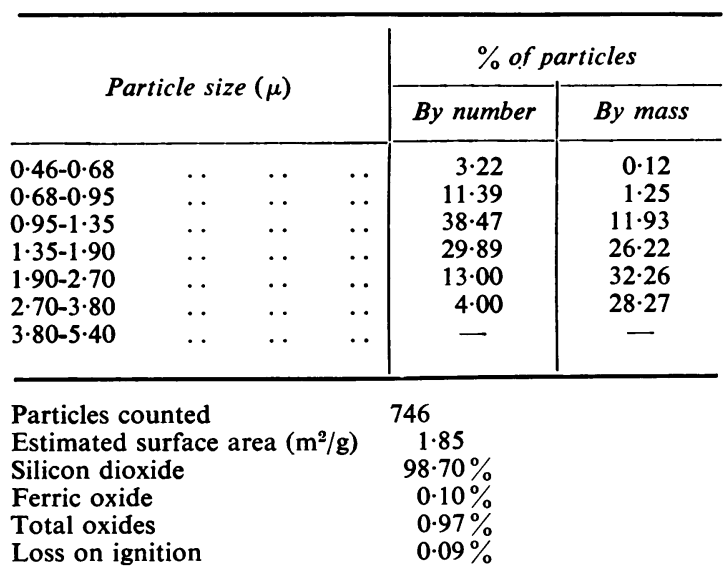

\section{Production of silicotic lesions}

After 10 days of feeding synthetic diets, the animals were inoculated intratracheally with $1 \mathrm{ml}$ of dust suspension (Zaidi, 1969) or with $1 \mathrm{ml}$ of sterilized physiological saline. The animals were maintained on their respective diets as before inoculation.

\section{Animals}

Albino rats from normal (not pathogen free) laboratory stock were used. They did not show evidence of bronchiectasis or other spontaneous lung infection. Male rats were used and weighed 150 to $200 \mathrm{~g}$ at the start of the experiments.

\section{Diets}

Experiment 1 Two diets were used.

Multideficient diet This was modelled on that eaten by miners:

$\begin{array}{lr}\text { Polished rice (Oryza sativa) } & 78.5 \% \\ \text { Red gram (Cajanus cajan) } & 5.0 \% \\ \text { Common salt (sodium chloride) } & 0.3 \% \\ \text { Leafy and non-leafy vegetables } & 10.3 \% \\ \text { Whole milk powder (Glaxo) } & 0.9 \% \\ \text { Arachis oil } & 5.0 \%\end{array}$

Dry weight analysis showed this to contain protein $8.6 \%$ carbohydrate $82.4 \%$, crude fibre $0.35 \%$, and fats $7.32 \%$. Minerals and vitamins were present only in traces.

Stock diet (control)

$\begin{array}{lr}\text { Wheat flour } & 54.9 \% \\ \text { Bengal gram (Cicer arietinum) } & 3.7 \% \\ \text { Leafy and non-leafy vegetables } & 36.6 \% \\ \text { Whole milk powder (Glaxo) } & 4.8 \%\end{array}$

Dry weight analysis showed protein $15.9 \%$, carbohydrate $73.3 \%$, crude fibre $2.3 \%$, and fats $4.5 \%$. Minerals and vitamins were present in adequate amounts.

Experiment 2 Both the experimental and control diets were entirely synthetic and the composition of both is given in Table 2. The main difference between the two diets is that the deficient diet contains only $4 \%$ protein compared with $20 \%$ for the controls.
TABLE 2

Composition of Protein Deficient

DIET

(Experiment 2)

\begin{tabular}{|c|c|c|c|}
\hline \multirow{2}{*}{\multicolumn{2}{|c|}{ Constituents }} & \multicolumn{2}{|c|}{ Level of dietary protein } \\
\hline & & $\begin{array}{c}20 \% \\
\text { control diet } \\
(g)\end{array}$ & $\begin{array}{c}4 \% \\
\text { deficient diet } \\
(g)\end{array}$ \\
\hline 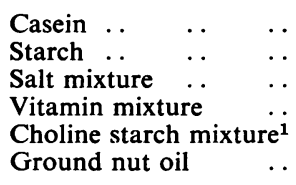 & $\begin{array}{l}\cdots \\
\cdots \\
\cdots \\
\cdots \\
\cdots \\
\cdots\end{array}$ & $\begin{array}{r}250 \cdot 0 \\
650 \cdot 0 \\
40 \cdot 0 \\
6 \cdot 0 \\
4 \cdot 0 \\
50 \cdot 0\end{array}$ & $\begin{array}{r}50 \cdot 0 \\
850 \cdot 0 \\
40 \cdot 0 \\
6 \cdot 0 \\
4 \cdot 0 \\
50 \cdot 0\end{array}$ \\
\hline
\end{tabular}

${ }^{1}$ This was prepared by mixing well choline chloride and starch in the ratio of $1: 3$.

\section{Histological methods}

The lungs were fixed in situ by injecting $10 \%$ formol saline into the trachea which was then tied before the thorax was opened. The lungs were removed intact and suspended in formol saline before longitudinal blocks were taken for routine embedding. Representative $5 \mu$ sections were cut and stained with haematoxylin and eosin, silver for reticulin (Gordon and Sweets, 1936), and alcian blue for acid mucopolysaccharide (Steedman, 1950). Microincineration was done, wherever indicated (Heppleston, 1963). Pathological grading of the lesions was assessed according to Belt and King (1945).

\section{Biochemical}

Collagen analysis All the lung tissue, except the portion used for histopathological studies, was dried at $110^{\circ} \mathrm{C}$. Tissue shavings and the paraffin embedded block was then added to it and the whole was treated thrice with xylene $37^{\circ} \mathrm{C}$. The mixture was then again dried till a constant weight was reached. This represented the total dry weight of lungs minus a few sections of $5 \mu$ thickness. A sample of the dried ground lung tissue was hydrolysed in $6 \mathrm{~N} \mathrm{HCl}$ in a sealed tube and kept for 16 hours at $100^{\circ} \mathrm{C}$ in a hot air oven. The hydrolysate was neutralized with the theoretical amount of $\mathrm{NaOH}$ and diluted as desired for analysis. In these samples hydroxyproline was estimated by the method of Stegemann (1958). Collagen contents were determined by multiplying the hydroxyproline value by $7 \cdot 46$.

\section{Procedures}

\section{Experiment 1}

Male albino stock rats were divided at random. Fortyseven were put on the multideficient diet and 40 on stock diet. After 10 days, 25 animals on the deficient diet and 21 on the stock diet were inoculated with quartz suspension intratracheally; the remainder were inoculated with saline. Survivors were kept on their diets and were killed off in batches of four or five in each group at 60, 120, 240, and $\mathbf{3 0 0}$ days from inoculation. 


\section{Experiment 2}

Male albino rats were divided at random and 51 were put on the low protein diet and 44 on the high protein diet. After 10 days, 25 animals on the low protein diet and 23 on the high protein diet were inoculated intratracheally with dust suspension; the remainder were inoculated with saline. Survivors were kept on their diets and killed off in small batches at $30,60,120$, and 180 days from inoculation.

\section{Results}

\section{Appearance, weight changes, and mortality}

The animals on the multideficient diet (Expt 1) maintained their weight gain well for two to four months (Fig. 1), then levelled off and finally lost weight when compared with those fed on the stock diet. Dryness of the fur, thinning, and alopecia developed and became progressively worse in the deficient animals but the stock diet group remained in good condition in spite of the dust inoculation.

In experiment 2 , the animals lost weight on the low protein diet throughout the experimental period whereas those on the high protein diet gained throughout. The low protein group showed more marked loss of hair than those in experiment 1 on the multideficient diet in spite of the shorter duration of experiment 2 . The animals on a high protein diet appeared normal and dust inoculation had no outward effect on either group.

A certain number of animals died immediately after the inoculations and there were further deaths during the course of the experiments. Details are given in Table 3. Because of autolysis it was not possible to determine the cause of the deaths which occurred later.

TABLE 3

Numbers of ANIMALS

\begin{tabular}{|c|c|c|c|c|c|}
\hline \multirow{2}{*}{ Expt } & \multirow{2}{*}{ Diet } & \multicolumn{4}{|c|}{ No. of animals } \\
\hline & & & Used & $\begin{array}{c}\text { Died } \\
\text { After } \\
\text { inoculation }\end{array}$ & Later \\
\hline 1 & $\begin{array}{l}\text { Multi- } \\
\text { deficient } \\
\text { Stock }\end{array}$ & $\begin{array}{l}47 \\
40\end{array}$ & $\begin{array}{lr}\text { Inoculated } & 25 \\
\text { Control } & 22 \\
\text { Inoculated } & 21 \\
\text { Control } & 19\end{array}$ & $\begin{array}{l}4 \\
- \\
4 \\
-\end{array}$ & $\begin{array}{l}2 \\
3 \\
0 \\
0\end{array}$ \\
\hline 2 & $\begin{array}{l}\text { Low protein } \\
\text { High protein }\end{array}$ & $\begin{array}{l}51 \\
44\end{array}$ & $\begin{array}{l}\text { Inoculated } 26 \\
\text { Control } \\
\text { Inoculated } 21 \\
\text { Control } 23\end{array}$ & $\begin{array}{l}4 \\
- \\
2 \\
-\end{array}$ & $\begin{array}{l}5 \\
3 \\
1 \\
1\end{array}$ \\
\hline
\end{tabular}

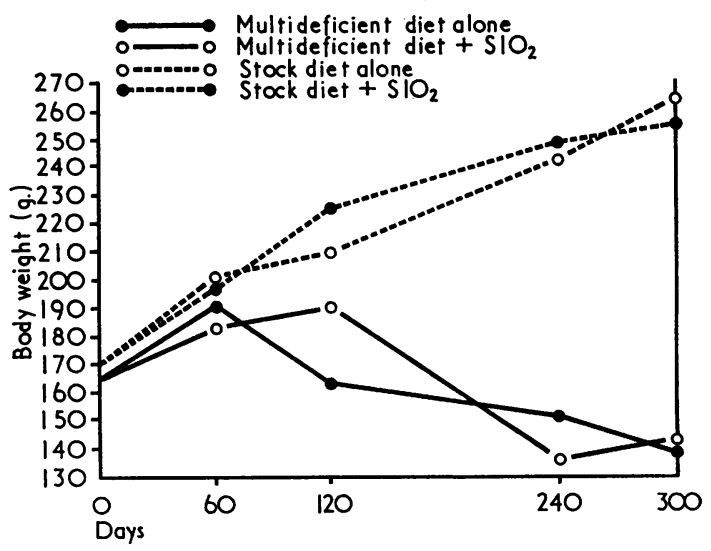

FIG. 1. Experiment 1. Weight changes in rats on the multideficient diet compared with animals fed the stock diet. The lack of effect of silica dust inoculations on weight change is also shown.

\section{Pathological findings}

Macroscopic In both experiments the young animals inoculated with silica showed subpleural collections of dust mainly over the dorsal surface of the lungs. These collections, which were at first diffuse, gradually became discrete foci on the dorsal and ventral aspects of the lung in the older animals. The mediastinal lymph nodes were enlarged at this stage.

There was no macroscopic abnormality in the lungs due to diet alone and diet had no influence on the macroscopic appearance of the dust collections.

Examination of the other organs showed no abnormality apart from atrophy of the spleen in animals on the multideficient diet.

The results of the application of the Belt and King (1945) method of grading silicotic fibrosis are shown in Table 4 . These indicate that diet had little effect on the development of fibrosis in either experiment. The general appearance of the nodules is shown in Figs 2 and 3. The more detailed histological findings are given below.

Microscopic In experiment 1 , at 60 days the silica inoculated animals on the multideficient diet showed thickening of the interalveolar septa and marked macrophage reaction. Clusters of macrophages were seen occupying the alveoli adjacent to respiratory bronchioles. The macrophage clumps either occupied the whole of the alveolar lumen or formed a mass in the centre of an alveolus with a clear space around. At many places the macrophages had undergone degeneration and such foci contained a mass of cytoplasm and a few nuclear remnants. On silver impregnation there was proliferation of tiny reticulin fibres in the interalveolar septa. 
TABLE 4

Effect of Diet on Progress of Silicotic Fibrosis by Grading Method of BeLt AND KING (1945)

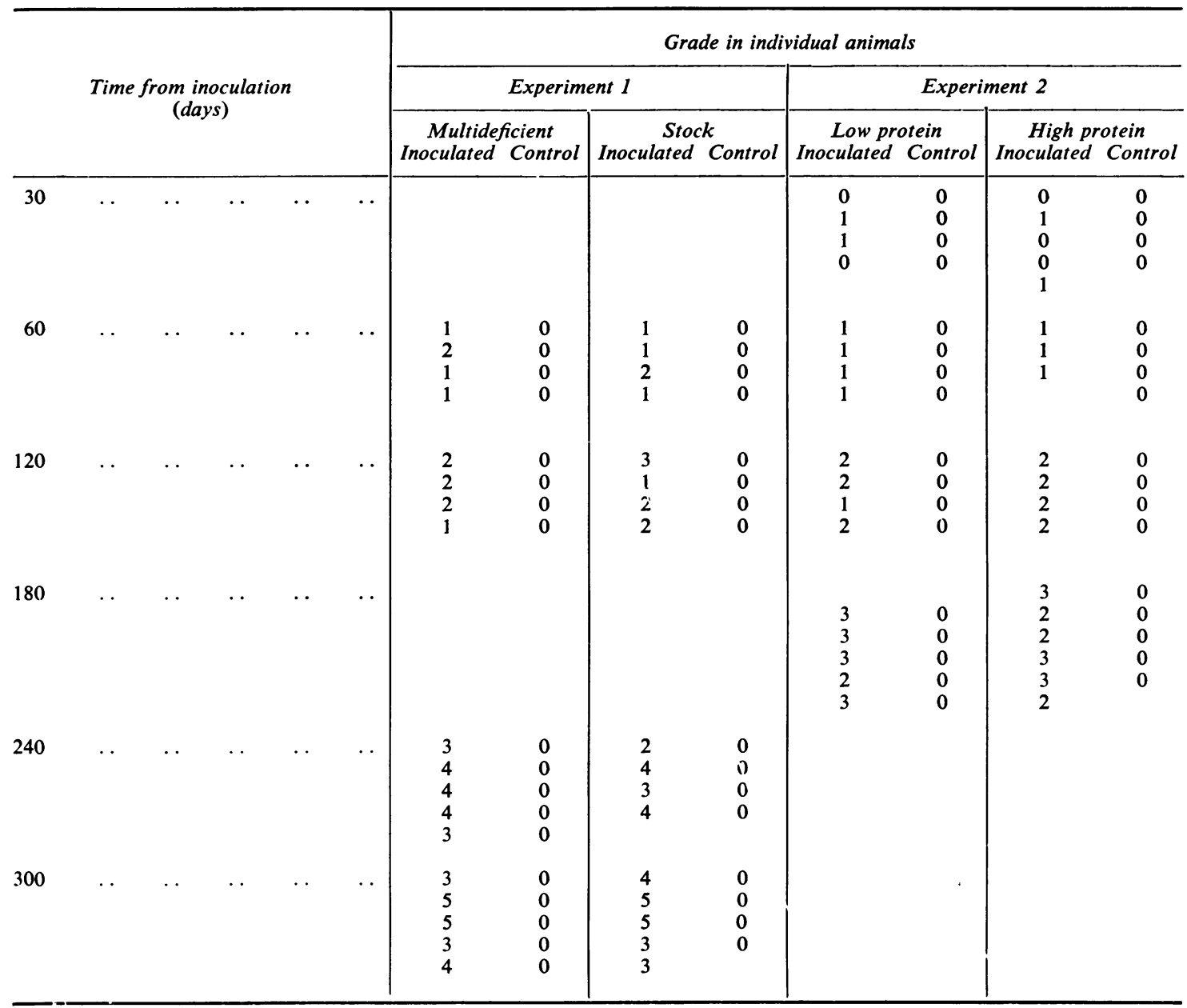

The reticulin fibres encroached on the alveolar lumen where macrophage aggregates were present. Alcian blue positive material and PAS positive granules were present in both individual macrophages and their aggregates. Besides macrophages there were also a few plasma cells and lymphocytes. Microincineration showed clumps of dust corresponding to areas occupied by cellular aggregates.

After 120 days, the dust cell aggregates were bigger but their situation was similar to that observed at 60 days; intra-alveolar aggregation of macrophages was less clear cut. Alveoli remote from respiratory bronchioles and alveolar ducts were mostly free of any cellular material. The macrophages when observed singly were PAS positive: The reticulin fibres were thicker and arranged in a compact net- work in the nodules. The alveolar walls also exhibited increased proliferation of reticulin fibres. The alcian blue positive materials were in larger quantities than had been observed previously.

After 240 days the size of the nodules had increased still further and they occupied large areas of lung parenchyma. The nodules at this stage contained only a few macrophages but large numbers of fibroblasts. Silver impregnation showed that the cellular nodules were composed mostly of collagen fibres among which there were a few reticulin fibres. Proliferation of reticulin in the alveolar septa was very slight. There were no alcian blue positive deposits anywhere in the lung tissue. The individual macrophages were PAS positive.

The further development of the disease process 


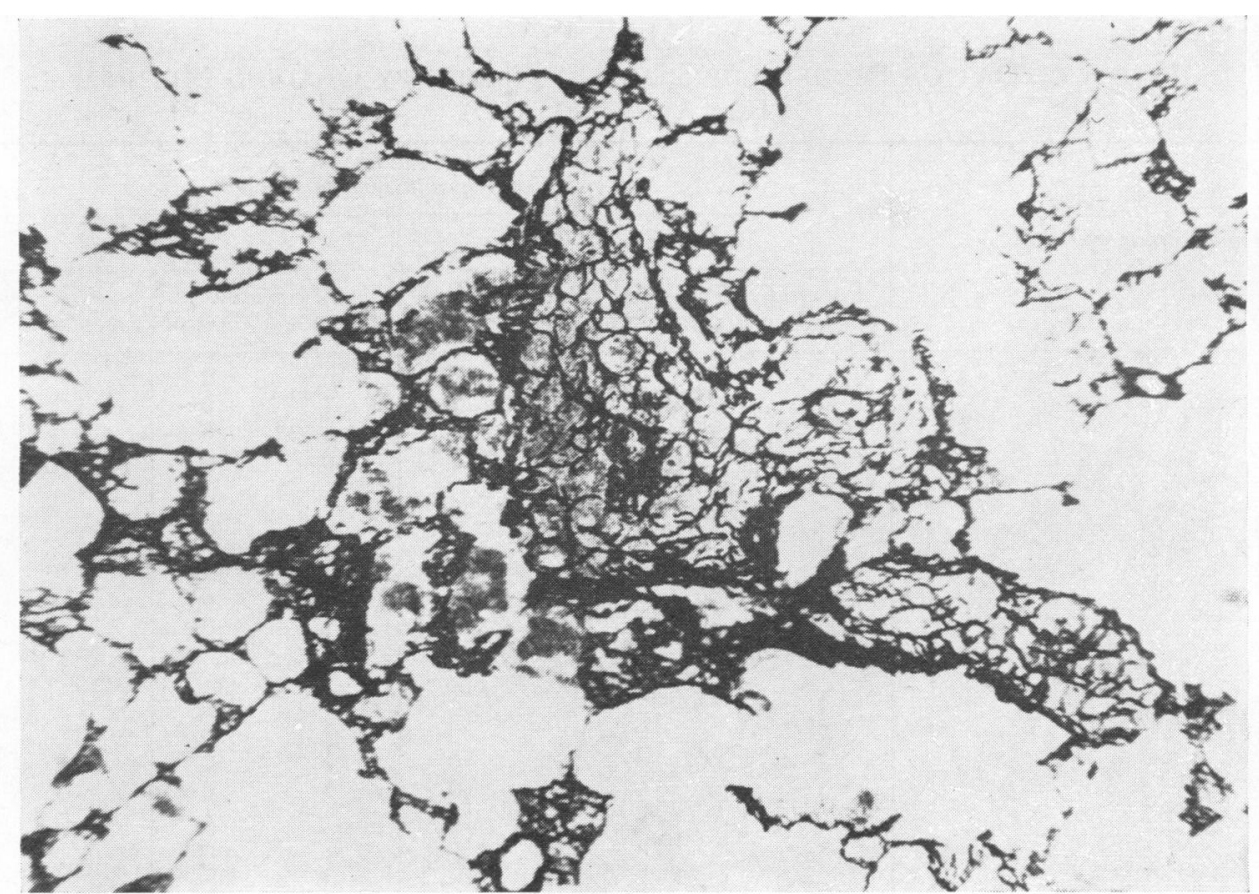

(a)

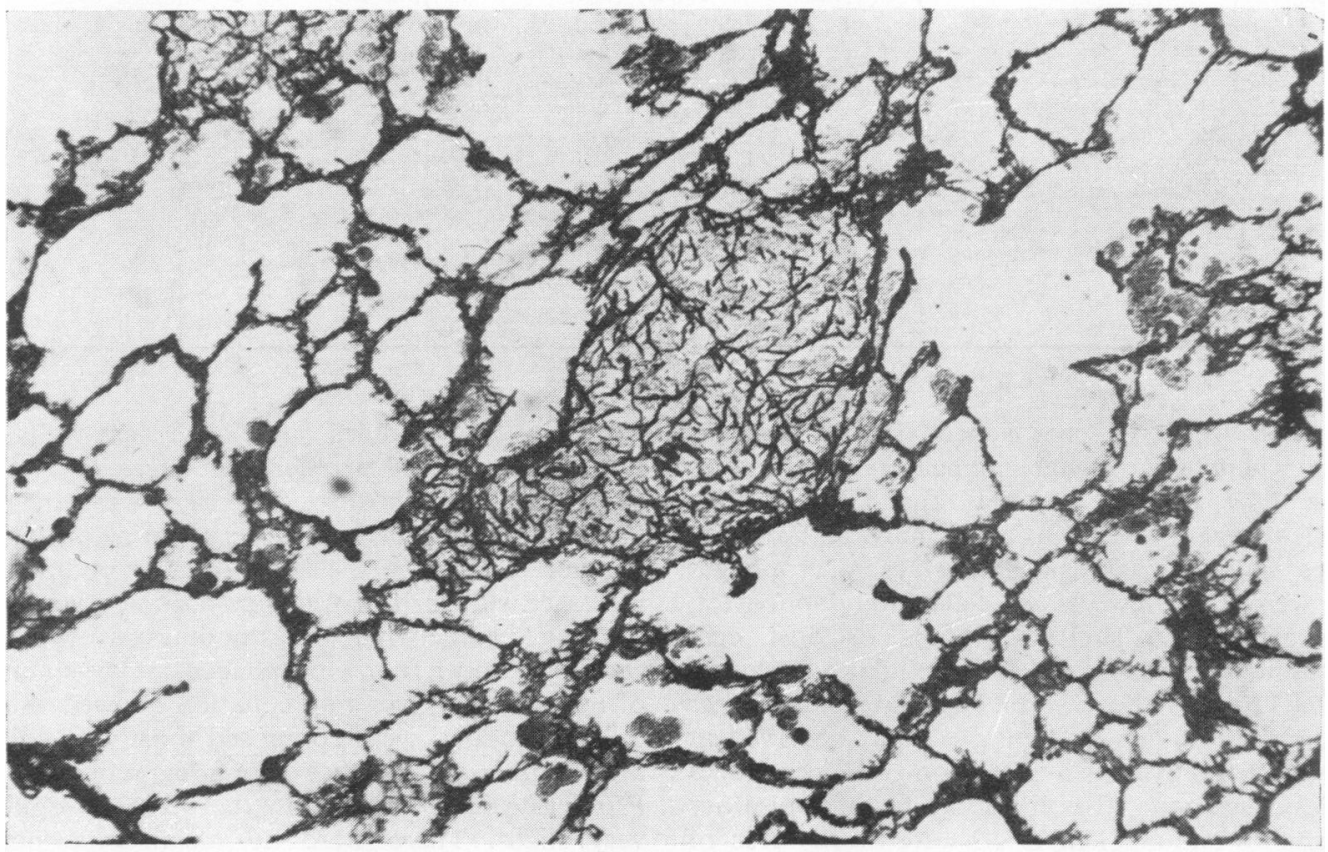

(b)

FIG. 2. Nodules, 120 days after inoculation (silver impregnation $\times 125) .($ a $) 4 \%$ protein diet; $(b) 20 \%$ protein diet. 


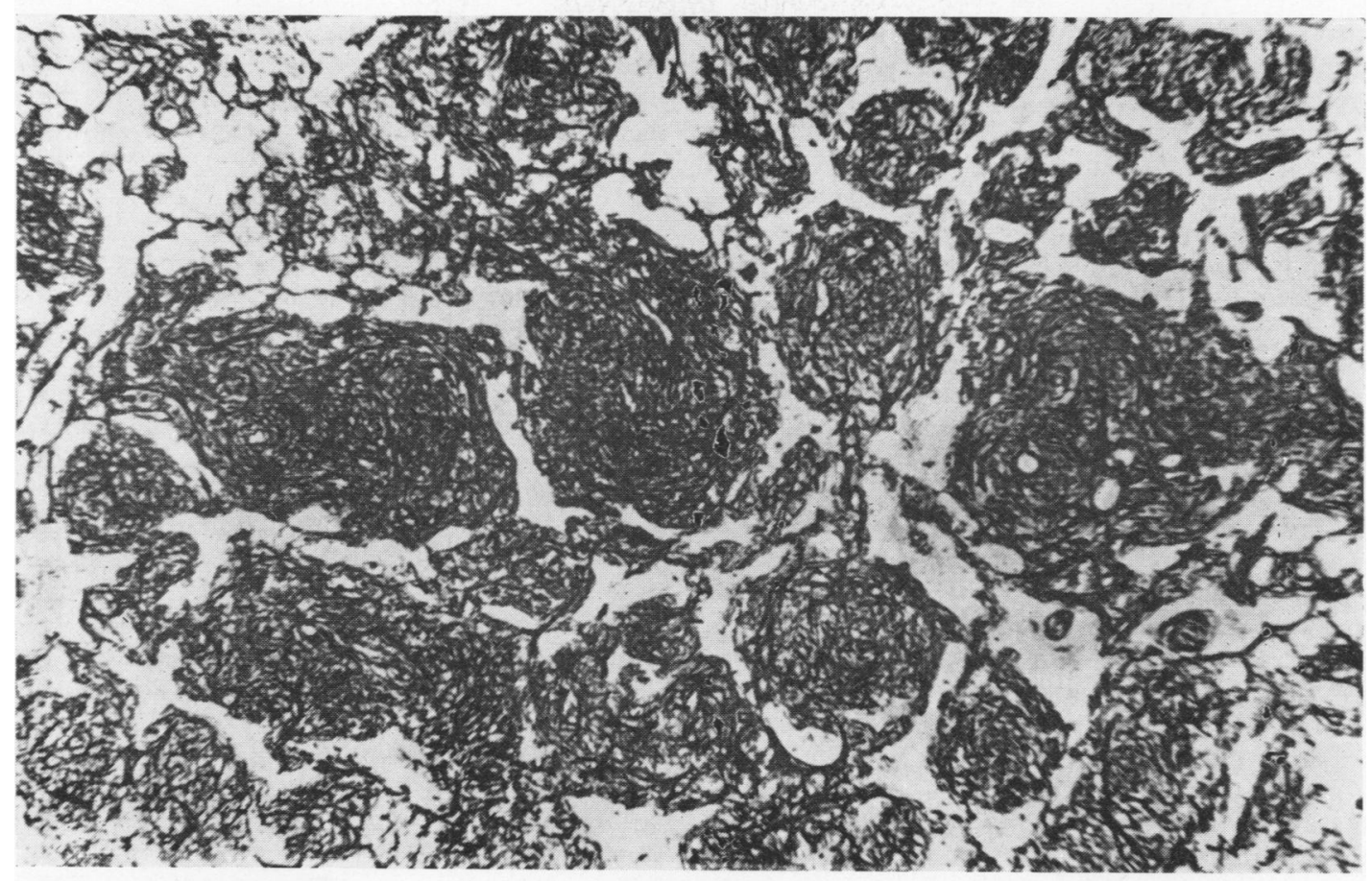

(a)

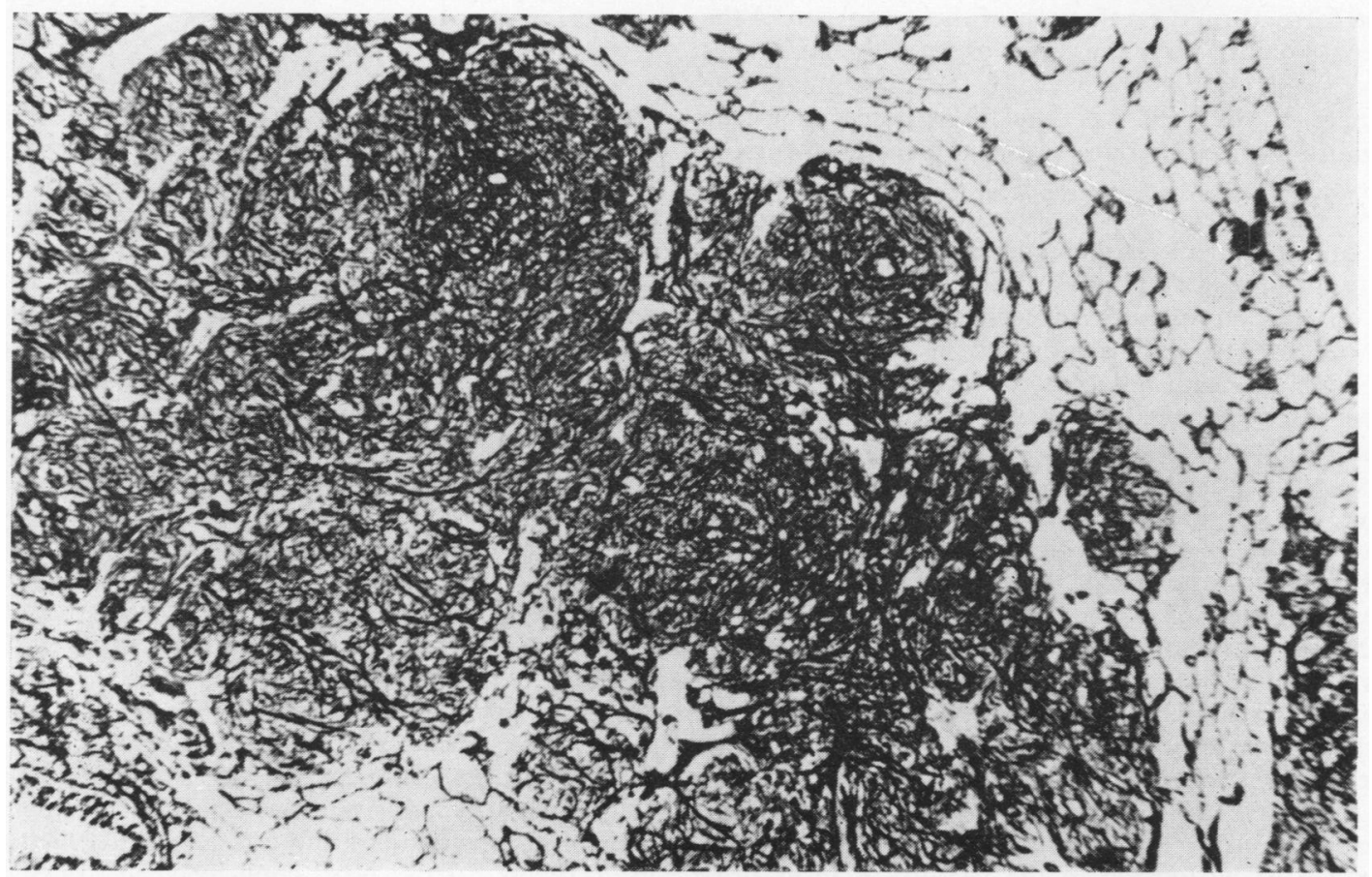

(b)

FIG. 3. Nodules, 300 days after inoculation (silver impregnation $\times 53$ ). (a) multideficient diet; (b) stock diet. 
up to 300 days in the lungs was essentially the same except that with the lapse of time the lesions became bigger and involved large areas. This reduced the functional respiratory area of the lung. A decrease in the cellularity of the lesions and an increase in collagen formation took place. Some alveoli in the vicinity of advanced silicotic lesions contained groups of macrophages. The alcian blue positive material was absent from the advanced nodules.

A perivenous and a periarterial space was seen in the lungs of many animals. This space encircled the lumen of blood vessels either partly or completely. Whereas in several lungs this space was empty, in others it contained a few cells, mostly lymphocytes and red blood corpuscles. The space was devoid of any lining cells.

In the lungs of silicotic animals which were fed stock diet the pathological changes were similar to those fed multideficient diet. Comparing two series of sections, one from lungs of silicotic rats fed with the stock diet and another from lungs of silicotic rats fed with the multideficient diet, it was not possible to decide by any criterion or with any degree of accuracy which diet produced more intensive silicosis or a greater degree of collagenization. Control animals did not reveal any comparable changes in the lung tissue.

The livers of rats fed multideficient diet revealed marked changes which first appeared at 120 days in the form of mild rarefaction of the cytoplasm of the hepatic cells. With the lapse of time these changes increased and at the end of the experiment, the nuclei of the cells were pushed towards one side against the cell membrane in the periportal region. Rats fed with the stock diet did not reveal any abnormality.

In experiment 2 the animals on a low protein diet, examined at 30 days after inoculation, showed intra-alveolar phagocytic cells containing quartz particles. The cells aggregated in clumps both in alveoli situated adjacent to alveolar ducts and respiratory bronchioles and sometimes in alveoli remote from these structures. A large number of free macrophages were also seen in the alveoli. When free, the cytoplasmic outline of the cells was clear, but in the aggregates it was not visible. Silver impregnation revealed thickening of the alveolar septa at regions where cellular aggregations were present. Invasion of the cellular aggregates by argyrophilic fibres was limited. Alcian blue positive material was present at the site of cellular aggregates which were shown, by microincineration and dark field examination, to contain clumps of silica dust. At 60 days the number of free macrophages was considerably reduced and more silicotic lesions tended to be located in the vicinity of respiratory bronchioles and alveolar ducts.

From this stage, the changes were indistinguishable from the findings in experiment 1 . The silica inoculated animals fed on a high protein diet were indistinguishable from those fed on a low protein diet. The control group in experiment 2 showed no abnormality.

\section{Biochemical changes}

The mean values and standard errors of the total dry weight of the lungs in the two experiments and the total and percentage collagen contents are given in Tables 5, 6, and 7 .

Compared with the controls, the animals inoculated with silica dust showed a progressive increase in total dry lung weight and in collagen content at all stages in both experiments. The increase was statistically significant $(P<0.01)$ in all instances and occurred whether the animals were fed on stock diet, on multideficient diet or on a high or low protein synthetic diet. In both experiments there was no significant difference between the gains observed in the deficient and non-deficient diet animals.

The control animals, not inoculated with silica dust, showed a much more gradual increase with age in total dry lung weight and total collagen content. The percentage collagen content tended to fall in these groups. There was no significant difference in either experiment between the deficient and non-deficient control animals.

\section{Discussion}

Many previous workers have investigated the effect of protein deficiency on collagen formation. Thompson, Ravdin, and Frank (1938) observed that the laying down of collagen fibres was diminished in the wounds of dogs severely depleted of proteins. Kobak, Benditt, Wissler, and Steffee (1947) confirmed this observation in rats and further observed a decrease in the maturation rate of fibroblasts. Chalkey, Algire, and Morris (1946) observed that, in the wounds of protein depleted mice, the appearance of new vascular buds was retarded. Findlay and Howes (1952) noted that the initial appearance and formation of granulation in healing wounds was not retarded unless the animals lost $20 \%$ of body weight by starvation and by protein depletion. Pearce, Foot, Jordan, Law, and Wantz (1960) reported a decrease in the fibroblastic proliferation in the healing of experimental wounds in animals fed on a protein depleted diet. Morrione (1949) studied the effects of various dietary regimes on hepatic fibrosis produced in rats by carbon tetrachloride and demonstrated a significant disappearance of fibrous tissue in those rats fed on a diet low in proteins. This was confirmed in 1958 by Sriramachari, who also stated (1960) that there were electron microscopic abnormalities in the 
TABLE 5

Influence of Diet and Silica Dust on Total Dry Lung Weight (g) ( \pm Standard error, figures for controls in brackets)

\begin{tabular}{|c|c|c|c|c|c|c|c|c|c|c|}
\hline & \multirow{2}{*}{\multicolumn{6}{|c|}{ Time from inoculation (days) }} & \multicolumn{2}{|c|}{ Experiment 1} & \multicolumn{2}{|c|}{ Experiment 2} \\
\hline & & & & & & & \multirow{2}{*}{$\begin{array}{c}\text { Multideficient } \\
225 \pm 8 \\
(225 \pm 8)\end{array}$} & \multirow{2}{*}{$\begin{array}{c}\text { Stock } \\
231 \pm 11 \\
(231 \pm 11)\end{array}$} & \multirow{2}{*}{$\begin{array}{c}\text { Low protein } \\
326 \pm 15 \\
(326 \pm 15)\end{array}$} & \multirow{2}{*}{$\begin{array}{c}\text { High protein } \\
318 \pm 21 \\
(318 \pm 21)\end{array}$} \\
\hline 0 & .. & .. & .. & .. & .. & .. & & & & \\
\hline $30 \ldots$ & .. & .. & .. & .. & .. & .. & - & - & $\begin{array}{c}434 \pm 17 \\
(312 \pm 13)\end{array}$ & $\begin{array}{c}437 \pm 24 \\
(327 \pm 28)\end{array}$ \\
\hline $60 \ldots$ & .. & .. & .. & .. & .. & .. & $\begin{array}{r}356 \pm 34 \\
(265 \pm 9)\end{array}$ & $\begin{array}{c}432 \pm 46 \\
(216 \pm 11)\end{array}$ & $\begin{array}{c}456 \pm 11 \\
(329 \pm 26)\end{array}$ & $\begin{array}{c}499 \pm 10 \\
(389 \pm 20)\end{array}$ \\
\hline $120 \ldots$ & .. & .. & .. & .. & .. & .. & $\begin{array}{c}560 \pm 46 \\
(249 \pm 10)\end{array}$ & $\begin{array}{r}520 \pm 31 \\
(237 \pm 5)\end{array}$ & $\begin{array}{c}521 \pm 19 \\
(342 \pm 15)\end{array}$ & $\begin{array}{c}540 \pm 29 \\
(379 \pm 30)\end{array}$ \\
\hline $180 \ldots$ & .. & .. & .. & .. & .. & .. & 一 & 一 & $\begin{array}{c}581 \pm 27 \\
(345 \pm 20)\end{array}$ & $\begin{array}{c}548 \pm 25 \\
(382 \pm 20)\end{array}$ \\
\hline $240 \ldots$ & .. & .. & .. & .. & .. & .. & $\begin{array}{c}526 \pm 28 \\
(272 \pm 18)\end{array}$ & $\begin{array}{r}591 \pm 49 \\
(262 \pm 14)\end{array}$ & - & - \\
\hline $300 \ldots$ & .. & .. & .. & .. & .. & .. & $\begin{array}{c}694 \pm 76 \\
(253 \pm 16)\end{array}$ & $\begin{array}{c}687 \pm 58 \\
(315 \pm 15)\end{array}$ & - & - \\
\hline
\end{tabular}

collagen fibres formed by protein depleted rats. Bhuyan and his colleagues (1965) observed that lack of fibrosis in hepatic cirrhosis induced by carbon tetrachloride in protein deficiency was due to the failure of mesenchymal response, with poor fibroblastic growth.
In experiment 1 , the diet was not only deficient in protein but also in essential amino acids and various minerals and vitamins. This diet did not impede the collagen response to silica dust in any way, as shown by both histological and biochemical studies at various intervals up to 300 days after inoculation.

TABLE 6

Effect of Diet and Silica Dust on Collagen Content of Lungs (mg of collagen per rat \pm standard error, controls in brackets)

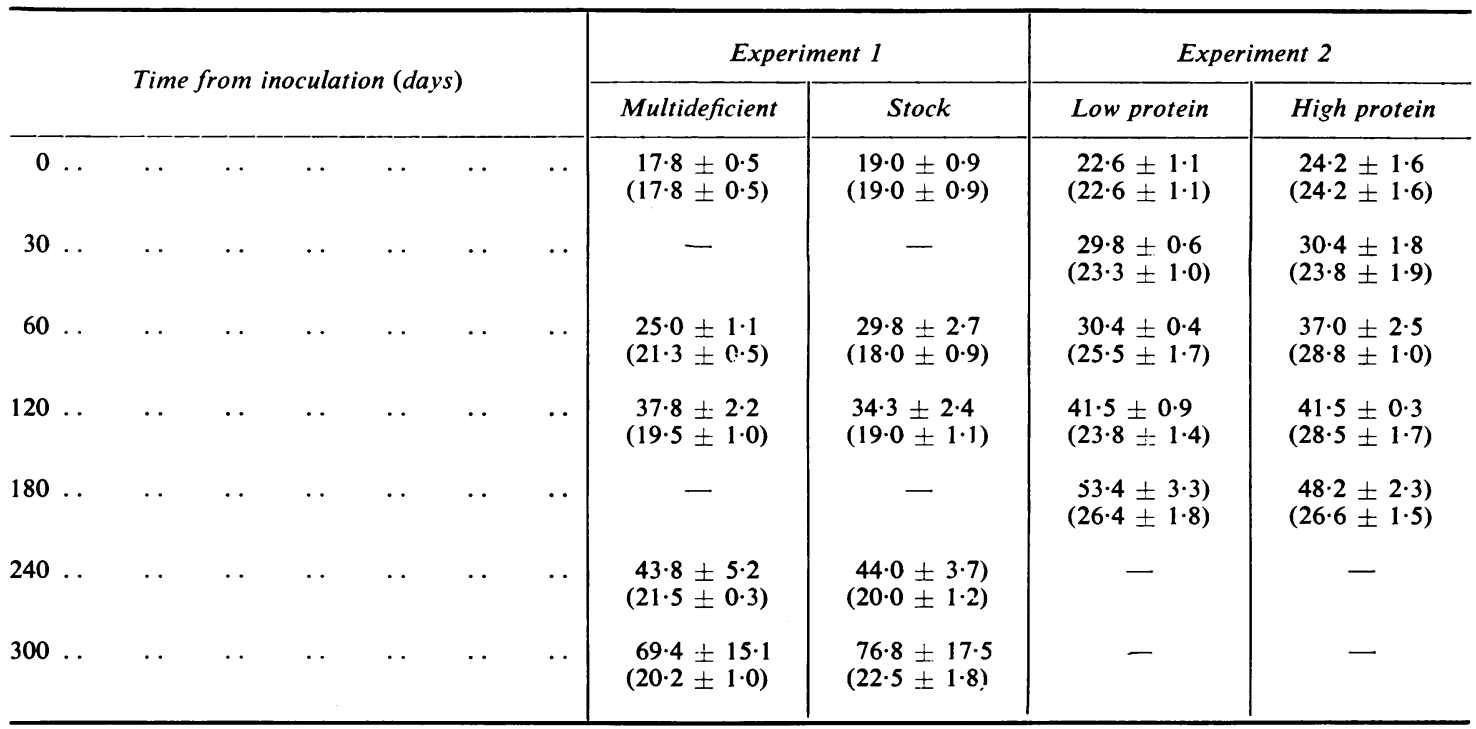


TABLE 7

Effect of Diet and Silica Dust on Percentage of Collagen in Lungs

(\% dry weight, controls in brackets)

\begin{tabular}{|c|c|c|c|c|}
\hline \multirow{2}{*}{$\begin{array}{c}\text { Time from } \\
\text { inoculation } \\
\quad \text { (days) }\end{array}$} & \multicolumn{2}{|c|}{ Experiment 1} & \multicolumn{2}{|c|}{ Experiment 2} \\
\hline & Multideficient & Stock & $\underset{\text { protein }}{\text { Low }}$ & $\underset{\text { protein }}{\text { High }}$ \\
\hline 0 & $\begin{array}{c}8.0 \\
(8.0)\end{array}$ & $\begin{array}{c}8 \cdot 2 \\
(8 \cdot 2)\end{array}$ & $\begin{array}{c}7.5 \\
(7.5)\end{array}$ & $\begin{array}{c}7 \cdot 5 \\
(7 \cdot 5)\end{array}$ \\
\hline 30 & - & - & $\begin{array}{c}6.9 \\
(7 \cdot 4)\end{array}$ & $\begin{array}{c}7 \cdot 0 \\
(7 \cdot 2)\end{array}$ \\
\hline 60 & $\begin{array}{c}7 \cdot 1 \\
(8 \cdot 0)\end{array}$ & $\begin{array}{l}6 \cdot 9 \\
(8 \cdot 3)\end{array}$ & $\begin{array}{c}7.4 \\
(7.8)\end{array}$ & $\begin{array}{c}7 \cdot 4 \\
(7 \cdot 4)\end{array}$ \\
\hline 120 & $\begin{array}{c}6.9 \\
(7.9)\end{array}$ & $\begin{array}{c}6.8 \\
(10 \cdot 0)\end{array}$ & $\begin{array}{c}8 \cdot 0 \\
(6.9)\end{array}$ & $\begin{array}{c}7 \cdot 8 \\
(7 \cdot 8)\end{array}$ \\
\hline 180 & - & - & $\begin{array}{c}9 \cdot 2 \\
(7 \cdot 6)\end{array}$ & $\begin{array}{c}8 \cdot 8 \\
(7 \cdot 4)\end{array}$ \\
\hline 240 & $\begin{array}{c}8 \cdot 2 \\
(8 \cdot 0)\end{array}$ & $\begin{array}{c}7 \cdot 4 \\
(7 \cdot 8)\end{array}$ & - & - \\
\hline 300 & $\begin{array}{c}9 \cdot 7 \\
(8 \cdot 0)\end{array}$ & $\begin{array}{l}10.7 \\
(7 \cdot 0)\end{array}$ & - & - \\
\hline
\end{tabular}

This shows that silica fibrogenesis can be supported by a small total dietary protein intake. The diet was even deficient in the amino acids which Stary et al. (1966) have shown to be essential for the formation of collagen precursors.

Experiment 2 was carried out to determine whether protein deficiency, such as has been shown to interfere with collagen formation in other circumstances, would interfere with collagen formation due to silica. Gross (1967) observed that, in silicosis, reticulin fibres are not elaborated by fibroblasts but by macrophages. In experiment 2 , reticulin fibres were already formed long before the fibroblasts appeared at about 120 days after inoculation with dust. It is possibly this difference in the mode of collagen formation which accounts for failure of protein deficiency to influence the result.

It has been suggested that sulphomucopolysaccharides are essential for collagen fibre formation (Layton, Frankel, Sher, Scapa, and Friedler (1958). Dunphy, Udupa, and Edwards (1956) observed that in wound healing during protein deficiency the initial rise in the mucopolysaccharides is much less extensive but more prolonged than in normal healing. In silicotic nodulation mucopolysaccharide deposition was observed in the cytoplasm of individual macrophages and their aggregates. This deposition occurred early, before any fibroblasts could be seen, and its production was not decreased in protein deficient rats. Bairati, Clerici, and Esposito (1961) observed that the ground substance in silicosis is of abnormal composition. There is little published work on multiple dietary deficiency and collagen formation.

An increase in the dry weight of lungs has been a constant finding in silicotic animals of our experiments. King, Maguire, and Nagelschmidt (1956) believed that the excess production of collagen in silicosis may be responsible for an increase in lung dry weight. In our experiments under conditions of malnutrition, an increase in lung weight was noticed quite early and at a time when only a small increase in collagen formation could be detected either histopathologically or biochemically. An increase in the water content of silicotic lungs has also been held responsible for increased lung weight (Antweiler, Baumann, and Schiller, 1962). In the present investigations this cannot account for the increase in the lung weight as the lung was weighed dry. It therefore seems more probable that other factors such as an increase in lipid content may have contributed either singly or jointly to an overall increase in the dry weight of the lungs (Marks and Marasas, 1960).

In our experiments inability to observe any retardation of fibrosis under conditions of malnutrition may not be due to the slow turnover of collagen for the development of the nodule but to a peculiar environment provided by the lungs. Hruza and Fabry (1957) observed that the amounts of collagen in the liver decreased whereas that in the lungs increased during prolonged caloric undernutrition. The embryological and morphological differences are perhaps important in the laying down of collagen in certain conditions of pathological fibroplasia. This may also be true in the collagen synthesis of the silicotic nodule (Gross, 1967).

\section{Conclusion}

There is no evidence from these experiments that malnutrition among miners in India is likely to protect them from the pulmonary fibrosis produced by silica dust inhalation or to increase their susceptibility to silicosis.

Quartz powder used in this investigation was supplied by Dr. Atma Ram, Director, Central Glass and Ceramic Research Institute, Calcutta, and its analysis was performed by Dr. Ravi Prakash, Director, Geology and Mining, Uttar Pradesh.

Mr. Mohammad Waseem helped with the biochemical investigations, Mr. Pratap Singh provided technical assistance, Mr. Panangat A. George performed the statistical analysis, and Mr. Musleh Ahmad was responsible for the photomicrography. 


\section{References}

Antweiler, H., Baumann, H., and Schiller, E. (1962). The adjuvant effect in the development of silicosis in rat lungs (Histology and the hydroxyproline and histamine content of fibrotic lungs). Beitr. Silikose-Forsch., Heft, 75, pp. 59-87.

Aykroyd, W. R., and Krishnan, B. G. (1937). The deficiencies of the South Indian diet. Indian $J$. med. Res., 25, 367-372.

Bairati, A., Clerici, E., and Esposito, G. (1961). Proteina pura del collagene, mucopolisaccaridi e silicio nella fibrillogenesi 'in vitro'. Med. d. Lavoro, 52, 338-358.

Belt, T. H., and King, E. J. (1945). Chronic pulmonary disease in South Wales Coalminers. III. Experimental Studies. D. Tissue reactions produced experimentally by selected dusts from South Wales coalmines. In Spec. Rep. Ser. Med. Res. Coun. (Lond.) No. 250, pp. 29-68.

Bhuyan, U. N., Nayak, N. C., Deo, M. G., and Ramalingaswami, V. (1965). Effect of dietary protein on carbon tetrachloride-induced hepatic fibrogenesis in albino rats. Lab. Invest., 14, 184-190.

Chalkey, H. W., Algire, G. H., and Morris, H. P. (1946). Effect of the level of dietary protein on vascular repair in wounds. $J$. nat. Cancer Inst., 6, 363-372.

Chvapil, M. (1957). Der Einfluss von Unterernährung sowie von Diäten verschiedener Zusammensetzung auf die in der Rattenlunge und- leber enthaltene Menge von Skleroproteinen bei experimenteller Silikose. Arch. Gewerbepath. Gewerbehyg., 15, 377-390.

Dunphy, J. E., Udapa, K. N., and Edwards, L. C. (1956). Wound healing: A new perspective with particular reference to ascorbic acid deficiency. Ann. Surg., 144, 304-317.

Findlay, C. W., and Howes, E. L. (1952). The combined effect of cortisone and partial protein depletion on wound healing. New Engl. J. Med., 246, 597-604.

Gordon, H., and Sweets, H. H. Jr. (1936). A simple method for the silver impregnation of reticulum. Amer. J. Path., 12, 545-552.

Gross, P. (1967). The mechanisms of some structural alterations of the lung. Arch. Environm. Hlth, 14, 883-891.

Heppleston, A. G. (1963). Deposition and disposal of inhaled dust. Arch. Environm. Hlth, 7, 548-555.

Hruza, Z., and Fabry, P. (1957). Some metabolic and endocrine changes due to long lasting caloric undernutrition. Gerontologia (Basel), 1, 279-287.

King, E. J., Maguire, B. A., and Nagelschmidt, G. (1956). Further studies of the dust in lungs of coal-miners. Brit. J. industr. Med., 13, 9-23.
Kobak, M. W., Benditt, E. P., Wissler, R. W., and Steffee, C. H. (1947). The relation of protein deficiency to experimental wound healing. Surg. Gynec. Obstet., 85, 751-756.

Layton, L. L., Frankel, D. R., Sher, I. H., Scapa, S., and Friedler, G. (1958). Importance of the synthesis of acidic polysaccharide for wound healing. Nature (Lond.), 181, 1543-1544.

Marks, G. S., and Marasas, L. W. (1960). Changes in the lung lipids of rabbits and guinea-pigs exposed to the inhalation of silica dust. Brit. J. industr. Med., 17, 31-35.

Mason, E. D., Theophilus, F., and Frimodt-Möller, J. (1945). The influence of butter fat in the absence or presence of casein on growth in young rats on a rice diet. Indian J. med. Res., 33, 219-228.

Morrione, T. G. (1949). Factors influencing collagen content in experimental cirrhosis. Amer. J. Path., 25, 273-285.

Pearce, C. W., Foot, N. C., Jordan, G. L. Jr., Law, S. W., and Wantz, G. E., Jr. (1960). Effect and interrelation of testosterone, cortisone and protein nutrition on wound healing. Surg. Gynec. Obstet., 111, 274-284.

Sriramachari, S. (1958). Nutritional factors in the pathogenesis of hepatic cirrhosis. Part II. The effect of low protein diet on the mesenchymal response in $\mathrm{ccl}_{4}$ induced cirrhosis. Indian J. Path. Bact., 1, 35-44.

- (1960). Effect of dietary protein on the turnover of collagen in experimental dietary and toxic liver injury. Proceedings of a symposium on collagen. Pp. 351-369. Interscience Publishers, New York.

, Ramalingaswami, V., and Patwardhan, V. N. (1958). Partial replacement of rice with tapioca in poor rice diets. The effect on growth and liver structure in the albino rat. Brit. J. Nutr., 12, 8-12.

Stary, H. C., McMillan, G. C., and Weigensberg, B. I. (1966). Wound healing in lysine deficiency. Arch. Path., 82, 280-286.

Steedman, H. F. (1950). Quoted by Pearse, A. G. E. (1961). Histochemistry, Theoretical and Applied. 2nd ed., p. 838. Little, Brown, Boston.

Stegemann, H. (1958). Mikrobestimmung von Hydroxyprolin mit Chloramin-T und p-Dimethylaminobenzaldehyd. Hoppe-Seylers Z. physiol. Chem., 311, 41-45.

Thompson, W. D., Ravdin, I. S., and Frank, I. L. (1938). Effect of hypoproteinemia on wound disruption. Arch. Surg., 36, 500-508.

Zaidi, S. H. (1969). Experimental Pneumoconiosis. John Hopkins Press, Baltimore, Maryland.

Received for publication October 27, 1969 